\title{
Pseudo-Athanasian Homily on the Man Born Blind: Slavonic Sermon from an Unknown Greek Original
}

\author{
Irina M. Gritsevskaya \\ Professor, Novosibirsk High School of Military Command, Novosibirsk, \\ Russia \\ irgri@inbox.ru \\ Viacheslav V. Lytrynenko \\ Adjunct Professor, Charles University, Evangelical Theological Faculty, \\ Prague, Czech Republic \\ vyacheslav.lytrynenko@gmail.com
}

\begin{abstract}
The paper offers a textual analysis, Slavonic edition and English translation of the Homily on the Man Born Blind preserved in XIVth-century novoizvodnye triodion panegyrics. The homily is ascribed to Athanasius of Alexandria and is unknown among Greek sources.
\end{abstract}

\section{Keywords}

Homily on the Man Born Blind - novoizvodnye triodion panegyrics - Athanasius of Alexandria - Bulgarian homiliaries

Medieval Slavonic miscellanies are undoubtedly the most common type of book among Slavonic Mss. While still insufficiently studied, they attract increasing attention from scholars, and one of the factors that drives the need for studying the content of miscellanies and producing individual descriptions is their transmission of Greek texts that are no longer extant in their originals. One of such texts is the Homily on the Man Born Blind, whose textual analysis, Slavonic edition and English translation are offered in this paper.

In the Slavonic MSs, this writing is ascribed to Athanasius of Alexandria (296/8-373) and found among the set of homilies that formed a fixed corpus of 
the so-called novoizvodnye triodion panegyrics. These panegyrics appeared in the 6o-7os of xIvth century, and their origin is related to the monastic milieu of Mt. Athos in Greece. More specifically, they represent a special type of Bulgarian homiliaries that were formed out of newly translated Greek texts, many of which (though not all) were unknown to the Slavs before. In modern scholarship, the primary attention has been given to the menaion miscellanies, whereas the study of the panegyrics has been rather limited. Some of the most significant studies of the paneryics were done by K. Ivanova ${ }^{1}$ and, more recently, by E. Mirčeva. ${ }^{2}$ One specific work that deals with this type of miscellany belongs to K. Ivanova and E. Velkovska, whose article bears a title indicative of the limited research in this field: "Preliminary Notes Concerning the History of Novoizvodnye Triodion Panegyrics in Mt. Athos." 3

Among the texts that formed part of the fixed corpus of the triodion panegyrics we find six homilies that are ascribed to Athanasius of Alexandria. ${ }^{4}$ As we have shown in an earlier study, ${ }^{5}$ most of these texts are translations from the known Greek originals. Two of them were possibly composed by Basil of Seleucia (d. ca 458), two others either again by Basil or John Chrysostom (349-407), or Athanasius. One text belongs to an anonymous author, and there

1 К. Иванова, “Житийно-панегиричното наследство на Търновската книжовна школа в балканската ръкописна традиция" [K. Ivanova, "Living Panegyrical Legacy of the Tarnovo Literary School in the Balkan Manuscript Tradition”], in: Търновска книжовна школа (Втори международен симпозиум, Велико Търново, 2о-23 май 1976), София, 198о, том 2, pp. 193214. К. Иванова, "Новоизводните търновски сборници и въпросът за ролята на патриарх Евтимий в техния превод” ["Novoizvodnye Miscellanies of Tarnovo and the Question of the Role Played by the Patriarch Euthymius in their Translation"], Старобългарска литература, 25-26 (1991), pp. 124-134; К. Иванова, “За календарните триодни сборници, писани в Хилендарския манастир" [On the Triodion Calendar Miscellanies Written in the Hilandar Monastery], Старобългаристика, 36/3 (2012), pp. 11-28.

2 Е.Мирчева, Староизводните иновоизводните сборнищи-преводи, редаиии, преработки, книжовноезикови особености [E. Mirčeva, Staroizvodnye and Novoizvodnye Miscellanies: Translations, Redactions, Adaptations, and Literary Features], София, 2018.

3 К. Иванова, Е. Велковска, “Хиландарская рукопись № 404 (предварительные заметки к истории новоизводных Триодных панигириков на Афоне” [“Hilandar Manuscript 404: Preliminary Notes Concerning the History of Novoizvodnye Triodion Panegyrics in Mt. Athos"], in: Афон и славянский мир (Материалы международной научной конференции, посвященной 10оо-летию присутствия русских на Святой Горе, Белград, 16-18 мая, 2013), Святая Гора Афон, 2014, pp. 235-255.

4 Иванова, “Житийно-панегиричното наследство," p. 198.

5 В.В. Литвиненко, И.М. Грицевская, “Триодные гомилии псевдо-Афанасия Александрийского в новоизводных болгарских панигириках (гомилиариях)” [V.V. Lytvynenko, I.M. Gritsevskya, "Triodion Homilies of Pseudo-Athanasius of Alexandria in the Novoizvodnye Bulgarian Panygyrics (Homiliaries)"], forthcoming in Palaeobulgarica. 
is one whose Greek original we did not find, namely, the Homily on the Man

\section{Born Blind.}

Ivanova is aware of ten MS copies with the novoizvodnye triodion panegyrics (of which five are Bulgarian and five Serbian), whose dating ranges from the very origin of this miscellany up to the end of the XIvth century. ${ }^{6}$ However, most of these Mss do not have the entire cycle of the triodion readings, offering only parts of it instead. We know of only three MS copies of the XIVth-century triodion panegyric that contain the Homily on the Man Born Blind. The present study and edition of this homily is based on these three mss listed below:

1. Hilandar Monastery, $404,{ }^{7}$ dated to $1370-1380 / 1385 \cdot{ }^{8}$ Bulgarian orthography (henceforth Hil. 404).

2. Hilandar Monastery, 389 , last quarter of XIV century. ${ }^{9}$ Serbian (Raški) orthography (henceforth Hil. 389).

3. Rilla Monastery, ${ }^{10} 4 / 7$, the 8 os of XIV. ${ }^{11}$ Bulgarian orthography (henceforth Ril. 4/7).

Ivanova and Velkovska ${ }^{12}$ made a number of important points concerning these Mss. They suggest that novoizvodnye triodion panegyrics are completely fixed on the level of incipits and corpus of texts, representing thus a closed textual

6 Иванова, Велковска, “Хиландарская рукопись № 404," p. 238.

7 Digital scans of the Hilandar ms were provided by the Hilandar Research Library \& the Resource Center for Medieval Slavic Studies at the Ohio State University, USA. We express deep gratitude to the monks of the Hilandar Monastery in Mt. Athos and the colleagues at the osu for the possibility of working with these electronic copies.

The differences in the dating vary in different authors, but not much: (1) 1370-1380 is the dating given by Д. Богдановић, Каталог ћирилских рукописа манастира Хиландара [D. Bogdanovič, Catalogue of Cyrillic Manuscripts in the Hilandar Monastery], Београд, 1978 , p. 158; (2) 1375-1385 is the dating given by Р. Станковић, "Водени знаци хиландарских српских рукописних књига XIV века" ["Watermarks in the XIVth-century Serbian Manuscripts from the Hilandar"], in: Археографски прилози, Београд, 200о-20о1, бр. 22/23, pp. 58-59.

9 This codex containts the flowery triodion or pentecostarion, forming a single whole with the Hilandar Ms 388 that has the lenten triodion (Богдановић, Каталог ћирилских рукописа, pp. 152-153).

10 Digital scans of this ms were provided from the electronic archive of the Faculty of Slavonic philology at Sofia University of St. Kliment Ohridski. We express deep gratitude to the monks of Rilla Monastery and the colleagues of Sofia University, especially И. Христовой-Шомовой, for the possibility of working with these electronic copies.

On the dating, see Иванова, Велковска, “Хиландарская рукопись № 404," p. 239. For the description of this Ms, see Б. Христова, Д. Караджова, А. Икономова, Български ръкописи от XI-XVIII век запазени в България: Своден каталог [B. Khristova, D. Karadžova, A. Ikonomova, Bulgarian Manuscripts of XI-XVIII preserved in Bulgaria: Comprehensive Catalogue], София, 1982, том 1, pp. 54. 
tradition. Furthermore, Hil. 404, in their view, is a draft Ms containing a draft form of miscellany's corpus, though not of the translation of texts. The order of texts here is not yet fixed and rather chaotic, while in the later copies these texts would be arranged according to the church calendar. The scribe explains the disorder of texts by the fact that he did not receive the originals necessary

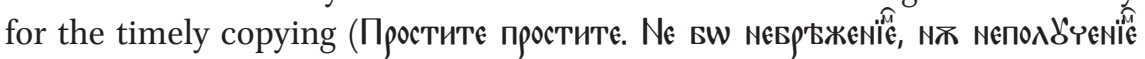

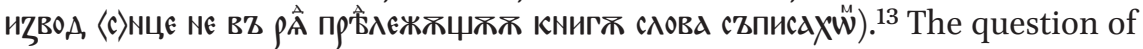
where these originals came from remains unclear. Zograf Monastery and the Monastery of Great Lavra in Mt. Athos are two likely places. What is clear, however, is that Hil. 404 was the protograph (or one of the protographs) for all other novoizvodnye triodion panegyrics.

With Hil. 404 as the base text, our collation of the Homily of the Man Born Blind in the three MSs made it possible to confirm the idea of the closed textual tradition of these miscellanies. Most of the differences between the MSS are orthographical. Hil. 389 exhibits the features of Serbian orthography that distinguishes it from the other two Mss with the Bulgarian orthography. According to Ivanova, the texts initially written in Bulgarian were transcribed with the Serbian orthography at the Hilandar Monastery, and she finds this reflected in the MS of the Hilandar Monastery 392 (henceforth Hil. 392), which the scribe named Iov copied from Hil. 404 between the years 1375 and 1385 . This Ms, however, does not contain the flowery portion of the cycle, and for that reason, Hil. 389 represents the earliest textual version of the panegyrics with Serbian orthography. In Ivanova's opinion, the Serbian transcription of Hil. 392 was done with absolute precision and consistency, and we found that the same is true of Hil. $389 .{ }^{14}$

We found only one significant lexical difference between the two Bulgarian MSS on the one hand, and the Serbian MS on the other. Both of the Bulgarian MSs use two related terms, zамоуждавдаше and zамбА'тнїе. Slavonic dictionaries provide an entry for zамоужАдти (trans. "to delay" or "slow down"), but not for бамоуждавати. ${ }^{15}$ However, the -вдти forms of the verb stressing the indefinite aspect were quite common. ${ }^{16}$ The imperfect form of this archaic verb, замоужАдавдашє, appearing first in Hil. 404, was rejected in both later MSs. In

13 "Forgive me, forgive me! For it is not by ignorance but because of not having received the manuscripts [on time] that I copied the homilies in this book without giving them proper order" (Hil. 404, f. 7v).

14 Иванова, Велковска, “Хиландарская рукопись № 404," p. 236.

15 See e.g., Словарь старославянского языка: а-и [Dictionary of the Old Slavonic Language: $a-i]$, Санкт-Петербург, 20о6, репр. изд., том 1, р. 648.

16 А. Вайан, Руководство по старославянскому языку [Handbook of the Old Slavonic Language], пер. с французского В.В. Бородич, Москва, 1952. 
Ril. 4/7, the scribe made a mistake in copying this verb and corrected

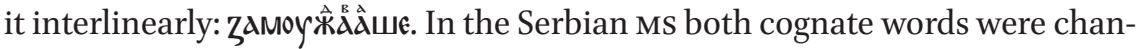
ged to zакьсн'Ввадше and zакьсн'њнїє.

One feature that makes Hil. 404 and Ril. 4/7 related to each other and different from Hil. 389 is the marginal gloss found in the Bulgarian Mss next to the account of the Pharisees' reaction: шскврьнны"̈ихь оустьнь", кАлотворца ха̃ марицдахоу ("with their defiled mouths, they called Christ a dirt-maker"). Since there are no scribal marks in the text of either Bulgarian Mss, this gloss could be perceived as a commentary that stood apart from the text, whereas in Hil. 389 it was integrated into the text from the margin. One other feature peculiar only to Hil. 389 is the statement кАлшмь прїємши ибвавлєеїє ("he received deliverance [from blindness] by means of clay"), as opposed to калшмь прїємши исправлєнїє ("he received correction [of sight] by means of clay") in Hil. 404 and Ril. 4/7. Since the words иzБАвлєнїє and иєпрАвлєнїє appear quite similar in form, the change in the Serbian manuscript could be as simple as the scribe's misreading of the initial term. However, if the change was intentional, it may indicate the fact that the scribe misunderstood the main idea of the episode in which the emphasis is not so much on the deliverance from blindness as on repairing (исправлємї) nature's failure.

In examining the content of the text, several points should be highlighted. First, the Homily on the Man Born Blind contains a rhetorical introduction whose points are not supported in the rest of the writing. Second, the text as a whole has a number of units that appear quite complete in themselves with each one interpreting chapter 9 of John's Gospel. The text composition as a whole could be briefly presented as follows:

1. Rhetorical Introduction (sect. I.1-2). Here, we find an analogy between the road-side shelters (припжтныє с'ьни) designed to give comfort from the weariness of traveling and the Church as a shelter of rest for those who are troubled by worldly cares. Just as a human host takes in the travelers, so does Christ, the host of strangers (страннопрїємєц, дшмоуӒвेкка), provide them with spiritual refuge on their life path (по житєискомоу птти $X$ WА,Ацї̈ оустрон СA).

2. The Fate of the Man Blind from Birth (sect. II.3) This section briefly describes the fact that the blind man lacked both food and sight, curiously pointing out that his mind was as quick to action as the movement of a deer (разоумом же Быстра ғакоже срZан).

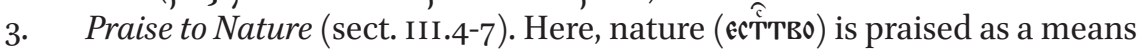
by which the blind man receives sight and as that which reveals Christ to be both God and Creator. In addition, a connection is drawn between the action in which Adam was formed from the dust of the ground and the action in which ground was used by Christ to make clay as a means of performing the blind man's healing. 
4. Supreme Submission of the Blind Man and his Healing (sect. IV.8-13). This section begins with the praise to the Lord for slowing down his grace (ZАмоужА,АВААШє жє В

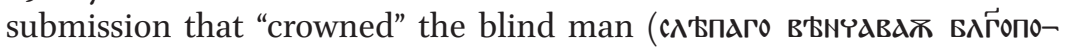
корство). Then follows a set of negative examples conjectured as possible responses that lack submission to the action of Christ in anointing the blind man's eyes with clay. And we also read about the response from the surrounding people who saw the blind man "rejoicing and leaping" (ра̂ужща са и скАчАџа), as he went about proclaiming the miracle of healing.

5. $\quad$ Pharisees Interrogate the Blind Man: Part One (sect. V.14-18). Here, we have an account of the first part of the Pharisees' interrogation of the formerly blind man. They are described as seeking a way to accuse Christ

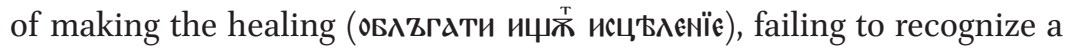
connection between the fact that God used clay to create Adam and Christ used it to give sight. It is said that the Pharisees put themselves into a logical contradiction: "If Christ broke the Sabbath, then how is it that the blind man was healed? And if the miracle was fake, then how could he break the Sabbath without having done anything?"

6. Pharisees Interrogate the Blind Man: Part Two (sect. v.19-29). The second part of the interrogation talks about the trap that the Pharisees set for the blind man: he had nothing but either to say that the law was not good or to insult Christ on account of the healing made on the Sabbath. The responses of the blind man are then compared to those of the Apostle Paul given to Agrippa (Acts 26:1-32), and it is said that the blind man proved himself to be self-consecrated to divine service even ahead of Paul (Саморжкополшжникъ покаба са пр'еждє павла). The Pharisees' interrogation is depicted as causing suffering to the blind man, but after having demonstrated proper resistance, "he is to be praised above all virtuous

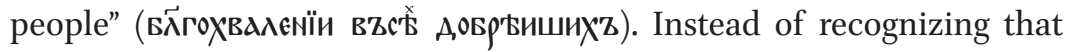
Christ was simply a prophet, the blind man pronounces an extended statement in which he confesses him to be above all other prophets of whom Moses prophesied long ago.

7. Conclusion (sect. vir.30-31). The homily ends with a rhetorical conclusion in which the reader is called to follow the good example of the faithful blind man. He is encouraged to purify his eyes from the spiritual darkness, keep the divine commands, and go on doing good deeds in love toward the Lord, who is God "that gives light" and sanctifies "every man coming into the world" ( $c f$.John 1:9). Notably, the conclusion says nothing that would support any points stated in the introduction. 
With this summary of the text, it is important to point out that the homily is enhanced with various rhetorical techniques. The introduction demonstrates what in modern scholarship is called "word-weaving" (from Slavonic: "pletenie sloves"), a high literary style forged "by the use of cognate and sound-like words, assonances, synonymy and speech rhymes in order to produce a peculiar verbally decorated effect"17 (see троуды and пжти). Other parts of the text include numerous other rhetorical devices, especially appeals, invocations, allusions, analogies, metaphors, parallelisms, moral instructions, and speeches spoken on behalf of different characters - both real ones (such as the blind man and the Pharisees), and imaginary (such as anyone exhibiting a lack of submission to Christ).

In our search for textual correspondence of the Slavonic homily with a Greek source, we examined the following material:

TABLE $1 \quad$ Homilies on the Blind Man's Healing from John 9:1-41

\begin{tabular}{|c|c|}
\hline Asterius of Amasea & 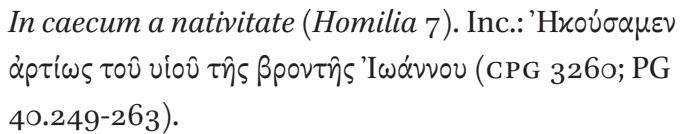 \\
\hline
\end{tabular}

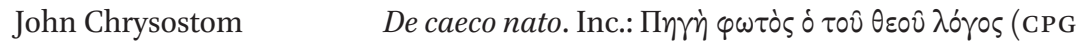
4582; PG 59.543-554). According to H.D. Altendorf, Untersuchungen zu Severian von Gabala, Tübingen, 1957, pp. 52-63, this homily belongs to Severian of Gabala.

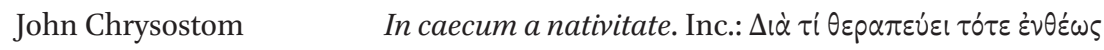

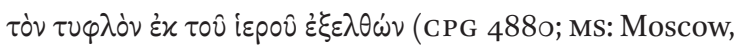
GIM, Sinod. gr. 234 [Vlad. 217], ff. 257-264).

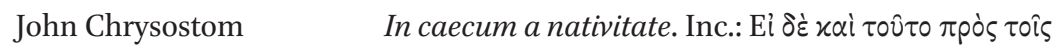

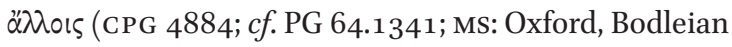
Library, MS. Auct. E. 3. 15; M. Aubineau, Codices Chrysostomici Graeci. I: Codices Britanniae et Hiberniae, Paris 1968, pp. 13, 150).

John Chrysostom

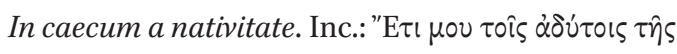

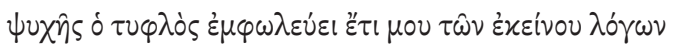

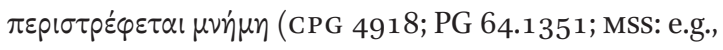
Mt. Athos, Koutloumousiou Monastery, 109; Grottaferrata, Biblioteca Statale del Monumento Nazionale di

17 Д.С. Лихачев, Исследования по древнерусской литературе [Studies on Old Russian Literature], Ленинград, 1987, p. 46. 
TABLE 1 Homilies on the Blind Man's Healing from John 9:1-41 (cont.)

Pseudo-Athanasius of

Alexandria, Timothy of

Jerusalem, Leontius of

Byzantium

Severian of Gabala
Grottaferrata, MS B. $\alpha .14$ [gr. 178]; Vatican, Biblioteca apostolica vaticana, Vat. gr. 455, ff. 75r-77v; Aubineau, Codices Chrysostomici Graeci, pp. 39, 15).

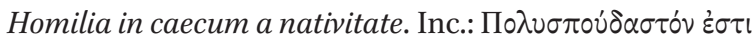

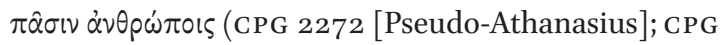
7409 [Timothy of Jerusalem]; CPG 7900.12 [Leontius of Byzantium]; PG 28.1001-1024).

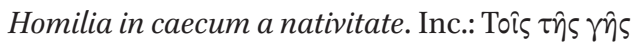

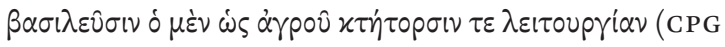
4231; MS: Paris gr., Bibliothèque nationale de France, 979, ff. 141r-144r).

Theophilius of Alexandria Homilia de caeco a nativitate (fragmentum) (Arabic version). Inc.: Agite dum, fratres et amici, communitas fidelium, uidete miraculum magnum quod lingua non potest dicere (CPG 2635; Ms: Monac. Arab. 1066, f. $5^{\text {r-v). }}$

TABLE 2 Greek Commentaries on the Blind Man's Healing from John 9:1-41

\begin{tabular}{ll}
\hline Euthymios Zigabenos & Expositio in Ioannem (PG 129.1305-1320). \\
John Chrysostom & In Iohannem homiliae LVI-LIX (CPG 4425; PG 59.305- \\
& $327)$. \\
Origen of Alexandria & Commentaria in Evangelium Joannis (E. Preuschen, ed., \\
& Der Johanneskommentar, Die griechischen christlichen \\
& Schriftsteller der ersten Jahrhunderte, 10, Berlin, 1903, \\
& Band 4, pp. 3-479; PG 14.21-830). A commentary on ch. \\
& 9 of John's Gospel is missing, but some fragments are \\
& preserved in catenae (see table 3). \\
& Commentarius in Ioannis Evangelium (CPG 5208. PG \\
& 73.939-1019) \\
Cyril of Alexandria & The commentary does not go beyond ch. 7 of John's \\
Theophylact of Ohrid & Gospel.
\end{tabular}


TABLE 3 Greek Exegetical Catenae on the Blind Man's Healing from John 9:1-41

Anonymous writer

Ammonius

Apollinaris of Laodicea

John Chrysostom

Isidore

Cyril of Alexandria

Origen

Severus of Antioch

Theodore of Heraclea

Theodore of Mopsuestia

$$
\text { patru }
$$$$
\begin{aligned}
& \text { 26o-261; I.-M. Vosté, ed., Theodori Mopsuesteni } \\
& \text { commentarius in Evangelium Iohannis Apostoli, Syr. IV,3, }
\end{aligned}
$$$$
\text { Corpus Scriptorum Christianorum Orientalium, 115; }
$$$$
\text { Scriptores Syri, 62, Leuven, 1940, 9.1-41, pp. 181-195. }
$$

Joannem, Antverpiae, 1630, Capita IX, pp. 246, 252, 258-26o.

Cordier, Catena patrum graecorum, Capita IX, pp. 247, 249, 253, 257, 259-26o; J. Reuss, ed., Johannes-Kommentare aus der griechischen Kirche aus Katenenhand-schriften gesammelt und herausgegeben, Texte und Untersuchungen zur Geschichte der altchristlichen Literatur, 89, Berlin, 1966, esp. frag. 317, p. 276.

Cordier, Catena patrum graecorum, Capita IX, pp. 250, 253, 255-256; Reuss, Johannes-kommentare, esp. frag. 49, p. 21.

Cordier, Catena patrum graecorum, Capita IX, pp. 247, 249, 252-253, 255-259.

Cordier, Catena patrum graecorum, Capita IX, p. 246. Cordier, Catena patrum graecorum, Capita IX, pp. 246247, 249-253, $25^{8}$.

Cordier, Catena patrum graecorum, Capita IX, pp. 251, 256, 258; Preuschen, Der Johanneskommentar, frags. 131-135, pp. 571-572.

Cordier, Catena patrum graecorum, Capita IX, pp. 247248, 250, 26o.

Cordier, Catena patrum graecorum, Capita IX, pp. 247, 251, 26o; J.A. Cramer, ed., Catenae in Evangelia S. Lucae et S. Joannis, Oxonii, 1844, p. 296; Reuss, Johannes -Kommentare aus der griechischen Kirche, frags. 71-82, pp. $85-87$.

Cramer, Catenae in Evangelia, p. 296; Cordier, Catena patrum graecorum, Capita IX, pp. 248, 254, 258,

Based on our analysis of this material, we can affirm that the Homily on the Man Born Blind is not identified among these sources. For that reason, it could be either a translation of the now lost Greek original, or perhaps a compilation 
of unidentified Greek texts. The homily exhibits numerous syntactical and lexical calques from Greek, though it is also possible that a Slavonic scribe from this time period could have stylized the text. ${ }^{18}$ Even though Slavonic MSs ascribe the homily to Athanasius of Alexandria, we did not find any textual parallels with either his genuine writings or pseudographic ones. We identified thirteen instances in seven genuine writings ${ }^{19}$ where Athanasius refers to the story of the blind man's healing, but none of them offer more than a simple allusion, and most of them are used to argue that Christ's power to restore sight proves him to be God. The pseudo-Athanasian Homily on the Man Born Blind (Homilia in caecum a nativitate CPG 7409; PG 28.1001-1024, see table 1) gives no textual parallels with the Slavonic text either.

The homily incorporates a number of themes that are commonplace in Greek exegesis. ${ }^{20}$ Thus, the fact that clay was used as a means for healing is often employed to show that Christ who healed the blind was also the Creator who made Adam from the dust of the ground (e.g., Origen, ${ }^{21}$ Ammonius, ${ }^{22}$ Pseudo-Athanasius, ${ }^{23}$ John Chrysostom $)^{24}$. An even more recurrent point in Greek exegesis is the argument that healing of the blind man proved Christ's

$18 \quad$ For the phenomenon of stylization in the Slavonic medieval literature originating with the literary reforms of the Patriarch Euthymius in the XIvth century in Tarnovo, see e.g., В.Д. Петрова, “Проблемы исихазма и древнеславянского 'плетение словес' в современной филологии” ["Problems of Hesychasm and Old Slavonic 'Word-weaving' in Contemporary Philology"], Вестник Чувашского университета, 1, (2011), 251-257.

19 Oratio contra Arianos, 3.32; 3.40; 3.41; 3.55 (K. Metzler, K. Savvidis, eds., Die Dogmatischen Schriften: Oratio III contra Arianos [Athanasius Werke], Berlin, 20oo, Band 1, Teil 1, Lieferung 3, pp. 343; 351-352; 352; 366); Tomus ad Antiochenos, 7 (H.C. Brennecke, U. Heil, A. Stockhausen, eds., Die "Apologien" [Athanasius Werke], Berlin, 2006, Band 2, Lieferung 8, p. 347); Epistula festalis, 11.4 (year 339) (PG 26.1406a-c); Epistula ad Adelphium, 3 (K. Savvidis, ed., Die Dogmatischen Schriften: Epistulae Dogmaticae Minores [Athanasius Werke], Berlin, 2016, Band 1, Teil 1, Lieferung 5, p. 745); De Incarnatione Verbi, 18; 23; 38; 49 (R.W. Thomson, Athanasius: Contra Gentes and De Incarnatione, Oxford, 1971, pp. 179; 191; 229; 257); Historia Arianorum, 61 (H.-G. Opitz, ed., Die "Apologien:" Historia Arianorum 32,2 - De synodis 13,2 [Athanasius Werke], Berlin, 2011, Band II, Lieferung 6, repr., p. 217); De decretis Nicaenae synodi, 1 (H.-G. Opitz, ed., Die “Apologien:" De decretis Nicaenae synodi 1,5-40,24 [Athanasius Werke], Berlin, 2012, Band II, Lieferung 1, repr., pp. 1-2).

For a helpful overview of the major patristic themes of exegesis on the healing of the blind, see J.C. Elowsky, ed., Ancient Christian Commentary on Scripture: New Testament IVa, John 1-10, Downers Grove, Illinois, 2007, pp. 318-336.

23 Homilia in caecum a nativitate, 4 (PG 28.1008a).

24 In Iohannem homiliae, 56 (PG 59.307-308). 
divinity (e.g., Pseudo-Athanasius, ${ }^{25}$ Cyril of Alexandria, ${ }^{26}$ John Chrysostom $)^{27}$. The motifs related to the logical traps and tricky questions from the Pharisees are especially elaborated in the commentary on the Gospel of John by Cyril of Alexandria. ${ }^{28}$ At the same time, the homily offers a handful of motifs that appear unique. Most significantly, it compares the blind man to the Apostles Peter and Paul; develops an idea of "slowed down grace;" and considers the Pharisaic interrogation of the blind in terms of sufferings that he had to endure for his faith and obedience to Christ.

In what follows, we will offer the Slavonic text of the homily based on three MSs (with Hil. 404 as a base text) along with the English translation. In rendering the Slavonic text, we made an effort to produce a literal translation that would reflect the nuances of Slavonic syntax and terminology (such as four

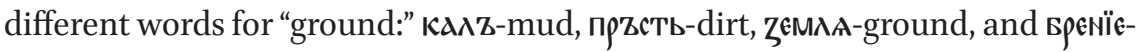
clay). All biblical citations (if not allusions) are given in italics. The text and translation are preceded by two tables: one for the Mss sigla and one for the abbreviations.

\section{Sigla}

A

B

C

\section{Abbreviations}

Ad $=$ ad

$C f .=$ confer

Emend. $=$ emendavit

Eras. $=$ erasit

In marg. = in margine

I.t. $=$ in textu

Lig. = ligatura

Lit. $=$ ad litteram

Mac. ob. = macula obscuratur

Sic. $=$ sic erat scriptum

Sup. $=$ supperscriptum
HM.SMS. 404, ff. 241v(a)-242v(a)

Rila Monastery 4/7, ff. 271r-273v

HM.SMS. 389, ff. 334v-339v
According to

Compare

Emendation

Erased

In margin

In the text

Ligature

Literally

Shaded stain

Thus, note

Written above the line

Omitted

Homilia in caecum a nativitate, 4 (PG 28.1008a).

26 Commentarius in Ioannis Evangelium, lib. 4, 9:33 (PG 73.1005b).

27 De caeco nato, 4 (PG 59.549).

28 Commentarius in Ioannis Evangelium, lib. 4, 9.1-41 (CPG 5208. PG 73.939-1019). 


$\begin{array}{ll}+ & \text { Added } \\ \mid< & \text { Emendations in the base text } \\ {[]} & \text { Line-divider on the folio } \\ & \text { Clarifications in the English translation } \\ \text { that are not part of the Slavonic text }\end{array}$

Text

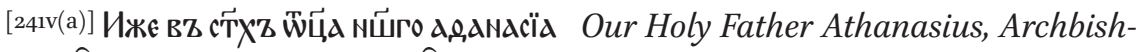
архїєกิ์

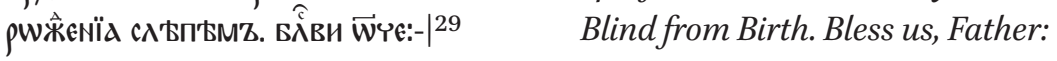

I.1.Трбдыы прохлаждажтъ| с'ии. и оутрбжАдены lieved by the road-side shelters that прїємшє, $\widetilde{W}$ пжтьшестZвнаго| УАаска- provide comfort from the hardships of

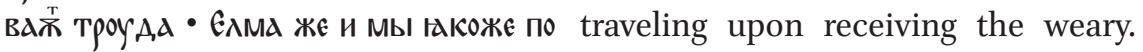
пжти N'E| КоєМZ ВZ жити ${ }^{31}$ шествоуємZ. Since we too live as if walking on a cerпжти же сего страдалїє| много, А,аршва tain life path, with many sufferings нӓ вZскаоО Б̈Z молитZвны ${ }^{32}$ с'Вни. along this path, God granted us prayer нє| тъчїж житеискы $\pi^{33}$ троуды, нж${ }^{34}$ shelters everywhere in order to pro-

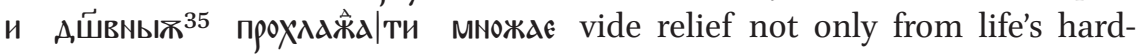

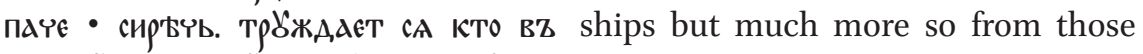
мирскьا⿱ попєченй, вZшё вZ црікшвь that have to do with the soul. That is, if ẆZXN木 anyone is troubled by the worldly cares, he finds rest on entering the church.

2. СБАить ${ }^{36}$ на жи|теистБмZ пжти 2. A host that finds himself placed страннопрїємецZ н'Бкыи. и иже вZ| along the life path takes in those who многопєчАловн'Мь пжти житїа ХшА,и- journey on this path of life and proвшїихъ $\widetilde{W}$ пж|ти приємь, ра злияными vides them with rest in manifold bed-

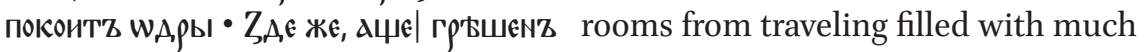
вьNид,єши ${ }^{37}$ ВZ покаАNїа С'Внь, sorrow. But here, if you enter a shelter

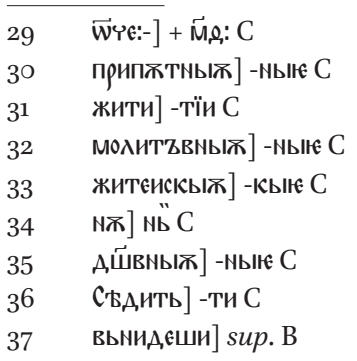


врZХХШвнын АПо|столШМ' и ключАрь ПрїЕМ ТА, ВZВWА,ИТZ вZ в'СЧнЫЖ|38 с'Вни - Аџе WБр'ВМененZ ${ }^{39}$ БЖА,ЕШИ ЖитїА сеГО и БWГА̃|

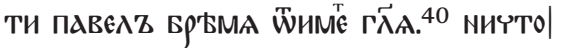

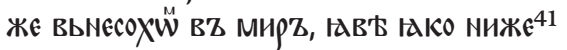
ИZNЕСТИ МОЖЕМZ •| [241v(b)] АЩЕ Б'АА,АМИ WБЬАТZ ПР̈̈НА,ЕШИ, ПОВРZГZ СЕБЕ NА

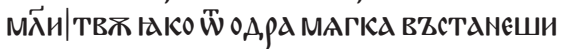

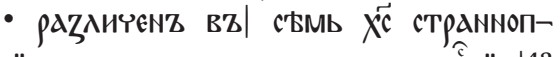

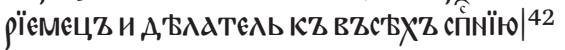

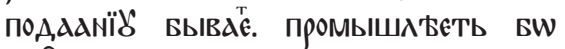

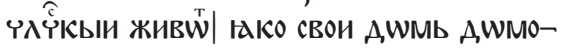

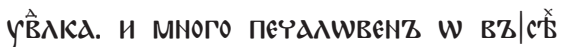
Иже ПО ЖИТеИскомоУ ПжТИ ХША,АЧї̈ оустрон са $\bullet$

of repentance as a sinner, you will be received by the supreme Apostle and key-keeper who will lead you to the eternal shelter. If you become burdened by the sorrows of this life and riches, Paul will immediately take away your burden by saying, "For we brought nothing into the world, and it is certain that we can carry nothing out" (1Tim. 6:7). If you come overwhelmed by trouble and turn to prayer, you will rise as if from a soft bed. In this, Christ is different [from others] as a host and maker of the salvation gift to all, for he governs human life as if it were his own house of which he is a steward and takes great care of all who journey on the life path by making them settled.

II.3. ИвW виА'' N'СКОГА, мимоХWА, на II.3. Thus, having once seen a man пжти сльпа, раzоу/мом жє Быстра whose eyes were blind but whose

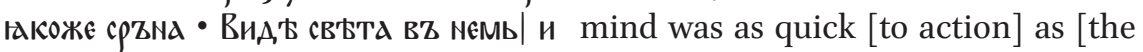

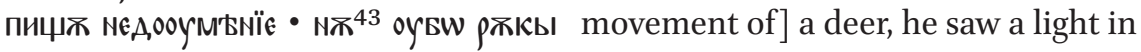

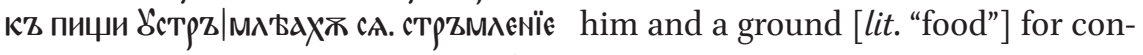
жє св'Бта очима nикако Же, пи|же fusion. For as his hands reached out

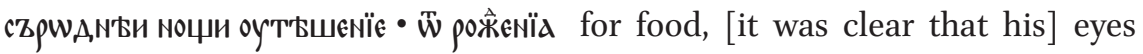
Бш хицоу| помрачемїє •

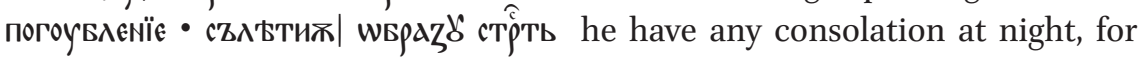
трдп'ьше - равнольтень паче же равно his vision was darkened from birth, his

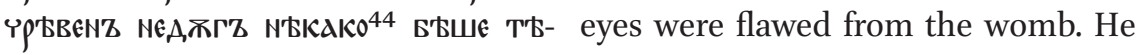

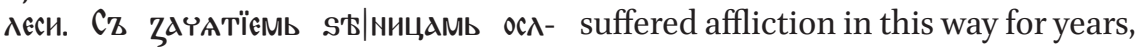
ьплємї, и вторше тр'ьвшвдашє өчима| for the disease was in the body for

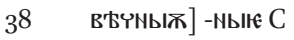

39 WБค'ВMENENZ]-M้Е์E์NZ B

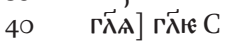

41 Іако пиже] ґакоже C

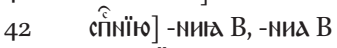

$43 \mathrm{~N}$ ] $\mathrm{Nb} \mathrm{C}$

44 N'BKAKo] N'É
} 
NAZА,ААNÏє, ихи прББЫВАТи вZ при-

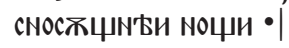

[his] entire age. Indeed, [as was said] somehow it was there when he was still in the womb. The pupils were blinded from the time of conception and the eyes required a second re-creation, or else to always remain in the dark.

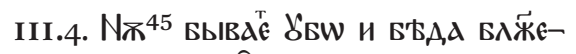

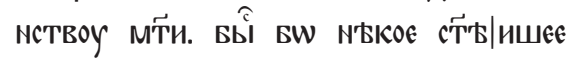

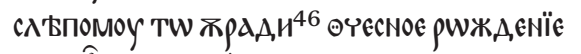

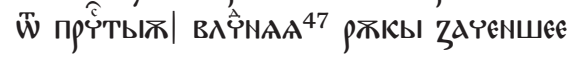
cA ${ }^{-}$

III.4. But as it sometimes happens, trouble [led] to the blissful experience of mercy, for something sacred happened to the blind that brought [him] joy over the [re]-birth of his eyes effected by the most holy hands of the Lord.

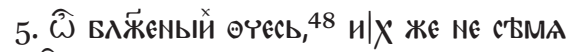

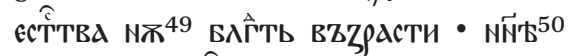

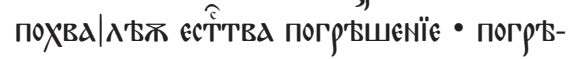
шьши ${ }^{51}$ БW, и сZ, В, Б, є $\lambda$ 它 $\left.\right|^{52}$ покAZа •

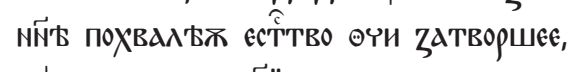

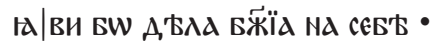

5. Oh, blessed eyes, nurtured not from the seed of nature but by grace! Now I am praising the nature that failed, for having failed, it revealed the Creator! Now I am praising the nature that closed the eyes, for it manifested God's deeds through itself!

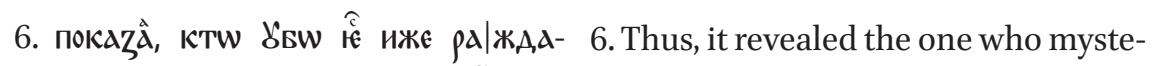
жщкж сA ${ }^{53}$ ФчИ ВZ АТршБА ${ }^{54}$ и riously makes [and] fashions the eyes

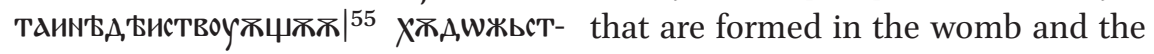
воужи,, 56 и ХжА,шжьство् ви,ца оne that made the blind see by means оустронвы.| и калшмь прїємши испрд- of [his] fashioning. [It revealed him]

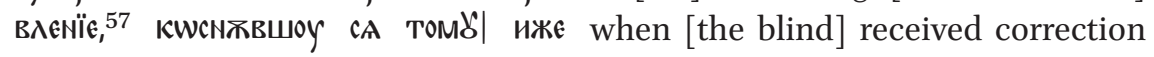

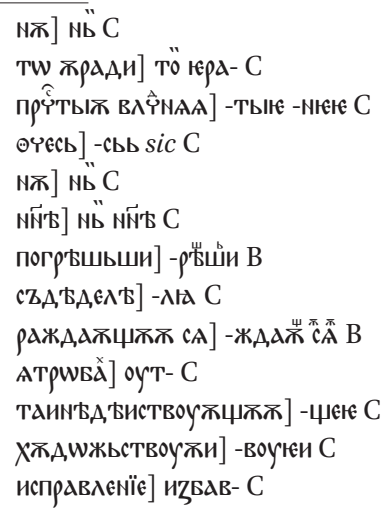




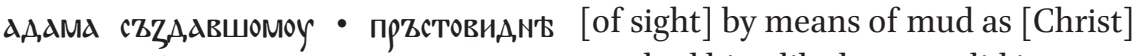

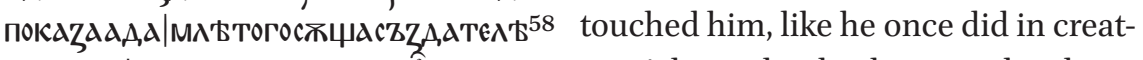

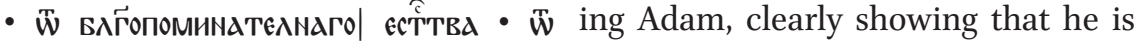

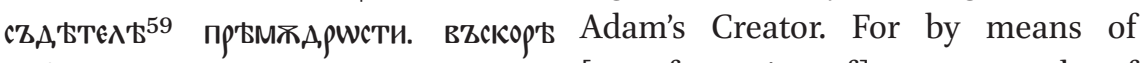

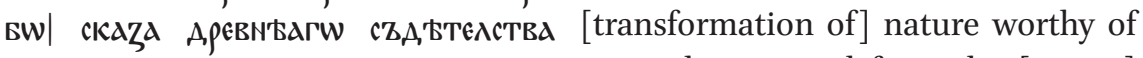

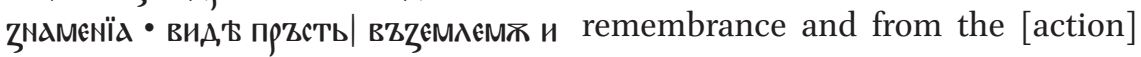
на тж $^{60}$ А,Оунжвша плюншвенїємZ, $и$ of the Maker of wisdom, soon came a

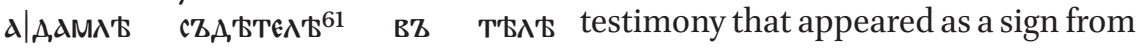
крыжџа сA поZNA • the old, as he saw him [with his spiritual eyes] taking dirt and breathing out the saliva, and recognized Adam's Maker hidden in the body.

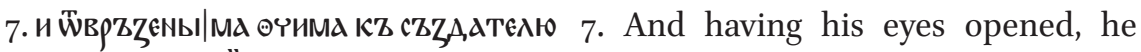
въZЫвААшє, тӹ съZ,А МА| в полшжи на мN' ржкж твож - ХотьЕшє| Lord, and "laid your hand on me"

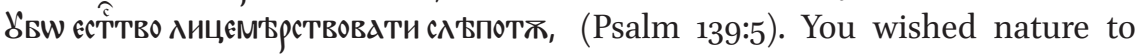

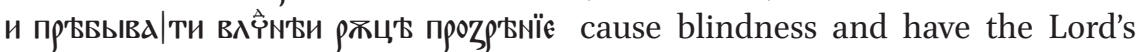
А,Ажчи •

hand that gives recovery of sight to rest upon $[\mathrm{me}]$.

VI.8. Фчима БW рж/кож пронбШёшєм', VI.8. Now, while the [blind's] eyes

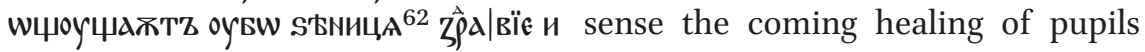

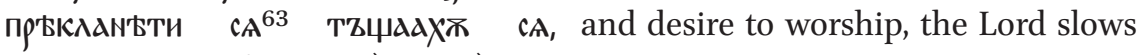

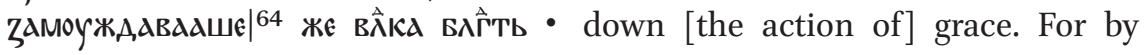
слWвомь оувш ${ }^{65}$ 'ккротьвваж $^{66}$ страсть, means of word he subdues affliction, про|А,АьжАваж ${ }^{67}$ жє пожА,АNїє $и$ prolongs the expectation and delay.

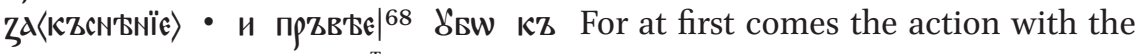
кала съа, ВанÏ̈ прихШай. потом же mud, and then [the blind] receives the помаZанїєе нa очноу прїємлеть. anointment on the eyes. Having reпрїємшоу жє, теци вZ сїлшамь ceived it, he is commanded to hurry to

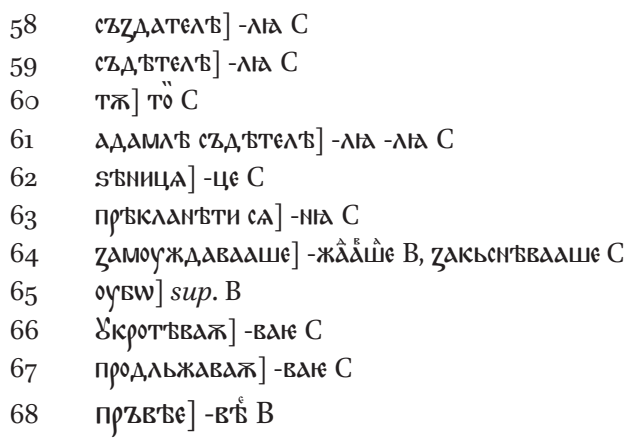




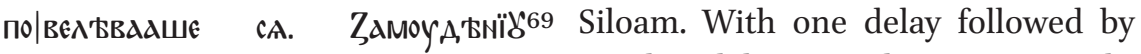

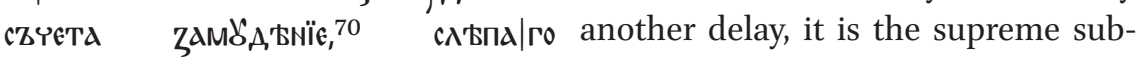
в'ВнчАВАж ${ }^{71}$ БАГ̈ОПОКорство. mission that crowns the blind.

9. Егш же абъ оувш и ш пръ|вый 9. Indeed, I am marveled even by his оудивльТ СА в'Вр'в. Іако калоу initial faith, for when mud was applied Прилагаємоу КZ өчимі| врачеванї̈ не to the eyes for healing, he showed no Пӧсмї̈а са видоу. и рткКама шсазавь sign of ridicule. And being blind and

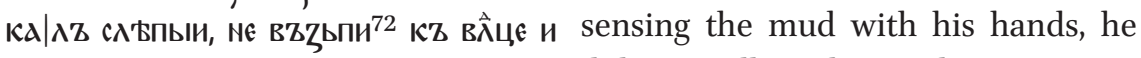

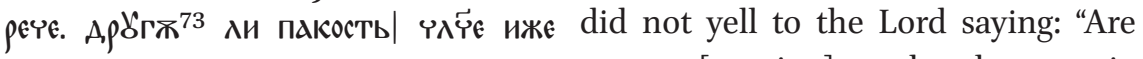
аце єси монма өчима прилшжи; you not [causing] another damage, sir,

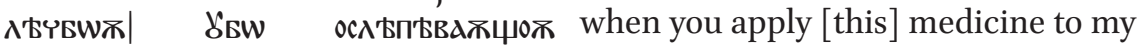
врачюєши; никто вш чисты ${ }^{74}$ и|м'ВА eyes for healing the blindness? For no

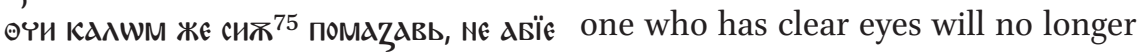

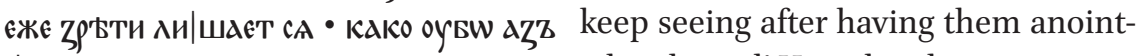

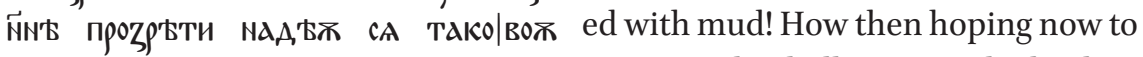
зравїє прїттивєцїл, ${ }^{76}$ ижє и зрациїй сл'Бпы творацеж $77 \cdot \mid$ that makes even those who see blind?"

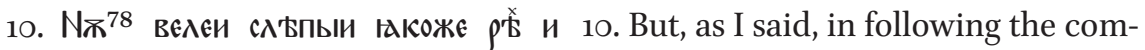
в'ьренZ. И Аже стодтелнжА в'Врк - С"̈ оувш того and in that he showed a firm faith. лоучьшжж ${ }^{80}$ в'ры єсть| достонно $и$ This then is the best case of faith and

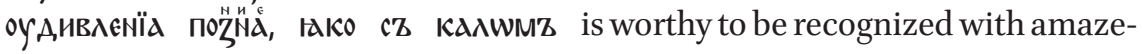
тєчии| [242r(a)] BZ сїлшамь повє $\lambda$ 'bNZ ment [for] how he was commanded to вывZ, Ne прогн'Вва са словẄ| на ї̈а. N $^{81}$ hurry to Siloam with mud [on himслышавь Іако иди вZ кжП'Б八 self] and did not become angry with

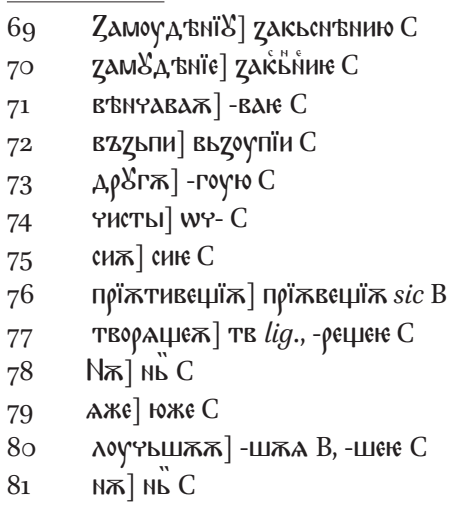


сїлшамла $\left.\right|^{82}$ и оумы са, и авїє the words of Jesus, but on hearing that ПОВє $\lambda$ БNNOє 83 ИСПАЬNИ.

he had to go to the Pool of Siloam and wash, he immediately fulfilled what was commanded.

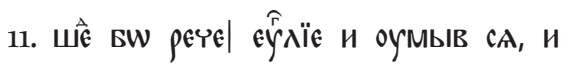

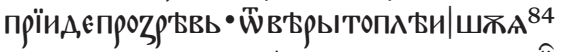

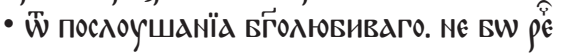

11. For the Gospel says that he went and washed, and on coming back, he received sight on account of his ferКZ $\vec{X} \boldsymbol{d} \mid$ єже достодше иномоу реци -

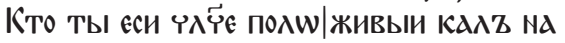

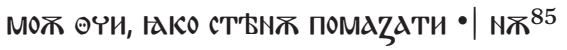
ВZс'ВКОГО ТАКОВАГО сАОВА СА'БПЫИ

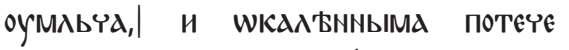

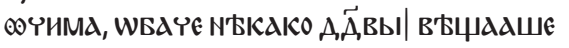

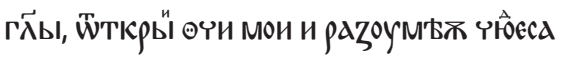
Ẅ za|кONa твоего •

vent faith [and] God-loving obedience. For he did not say to Christ as someone else would say: "Who are you, sir, to be placing mud on my eyes, as if plastering the wall?" But instead, the blind silenced all such words and headed on with muddy eyes, as if proclaiming the words of David: "Open my eyes and I will understand the wonders of your law" (Ps. 119:18).

12. сZWMыв ${ }^{86}$ жє кАлZ и т'Влєсноє 12 . Having washed off the mud and re-

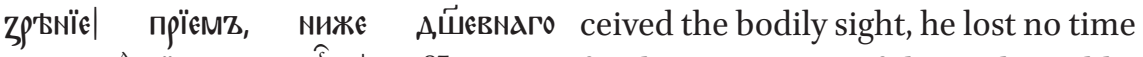

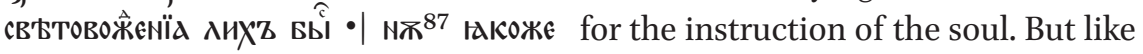

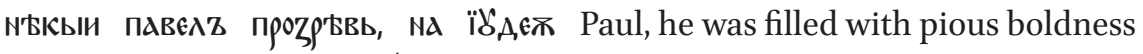
испльми са влГОчьстиваго toward the Jews - to those who enА.рZZновлємїа. и ср'ттажцй єго countered him, he displayed his sight,

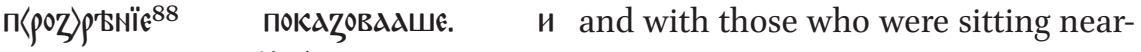

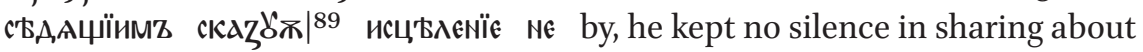
прғылъцадше - П'сснословїа распттїа| healing. He filled the streets and

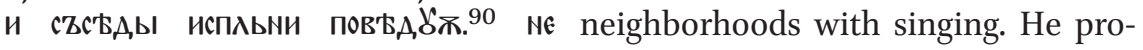

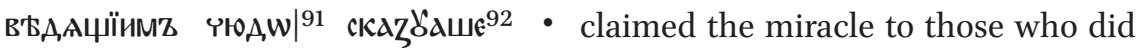

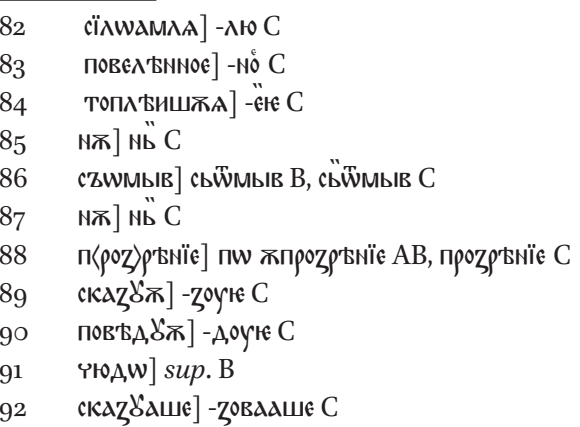


СZРWА, КИКШMZ пропов'ВА,ААше $・$

13. САЬШЖШЕИ КОУПнО И ВНА,АЧЕН

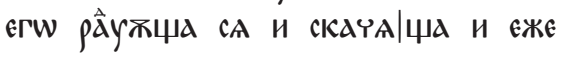

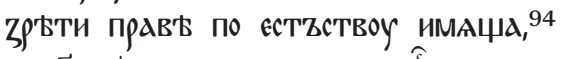
ГААа̃

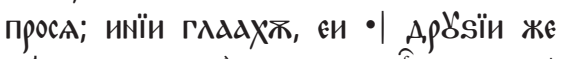

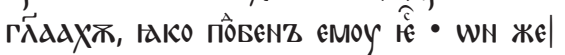

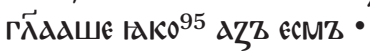

V.14. фарнсее W nemb сZПнрадХ⿸丆 сA $\bullet$ Гр’

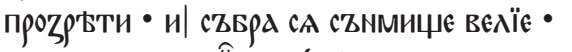

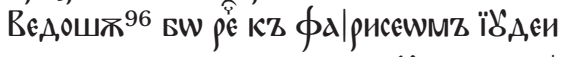

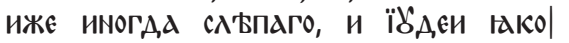
ШСжЖА, ЕнаА вZПрАшААХЖ, КАКО

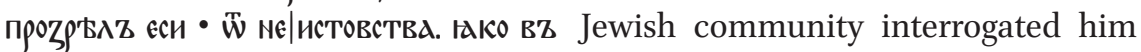

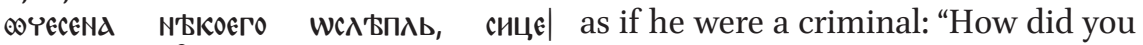

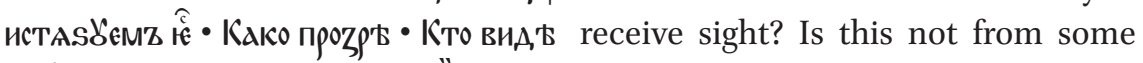

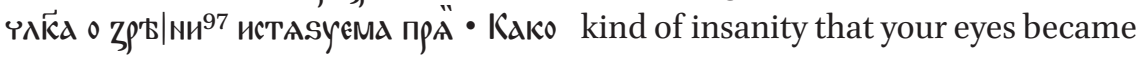

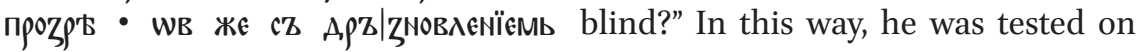

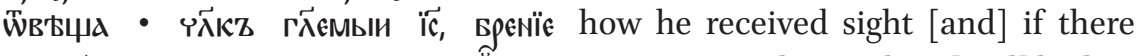

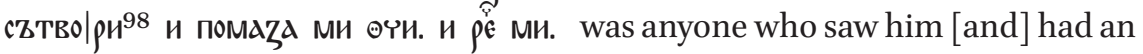
ид,и и оумы сА вЪ КжПФ

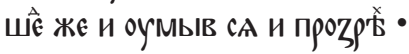

But he replied with boldness: "The man called Jesus, made clay and anointed my eyes, and said: 'Go and wash in the Pool of Siloam'. So, I went and washed and received sight" (John 9:11).

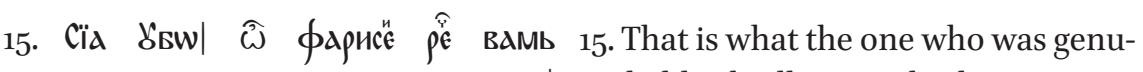

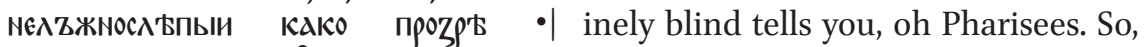

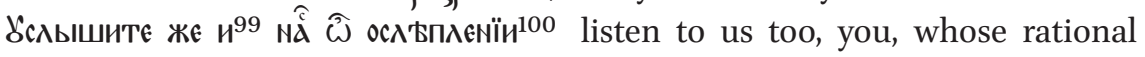

\begin{tabular}{|c|c|}
\hline 93 & ВИ,ААЧЕИ] -Чїи В \\
\hline 94 & ИМАЧА] ИМОУ- C \\
\hline 95 & [Ako] sup. B \\
\hline 9 & Вєд,шш] -шє C \\
\hline 9 & 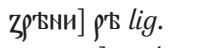 \\
\hline 98 & сътвори] тв lig. \\
\hline & $\mathrm{H}]+\mathrm{OC}$ \\
\hline & осльплєкїн] + и С \\
\hline
\end{tabular}




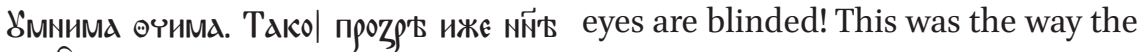

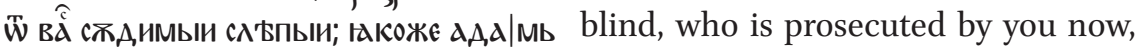
вренїємь съZАдамын. въZ прьсть $\widetilde{W}$ бємлА| и плююж, и полшжи аted with clay, so now too God took

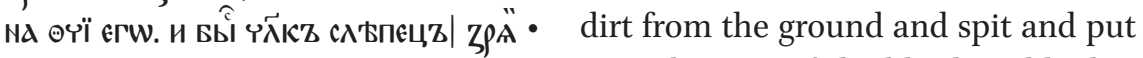
it on the eyes of the blind, and he began to see.

16. КАко про弓рФ - ОБАZГАти ищ

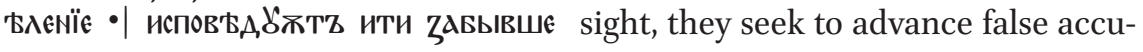
прогр'Бнїе •

sations against the healing [and] declare to move on, forgetting the fact that [the blind] received sight.

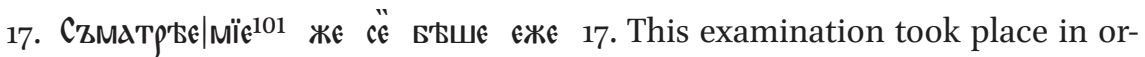

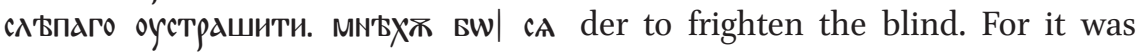
в'ррндаго оустрашити и н'Бкыи ме- their idea to frighten the faithful and тнжТи глаิ

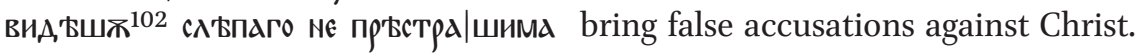
и врачеванїа БеъьвиновенZ видZ, But as they saw that the blind was not лихшимь|ствоужче пр'ввратишж са frightened and the healing appeared Na скБWтNOE WБеZ

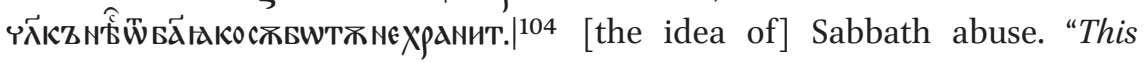
man", as it is said, "is not from God, for he does not keep the Sabbath" (John 9:16).

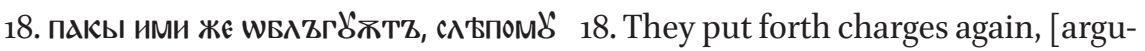

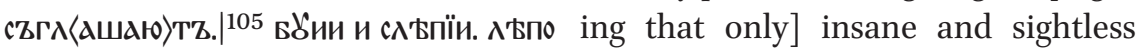
БW прїжтн106 на на ГКАА ${ }^{107}$ гласы $\bullet$ [could] agree with the blind, whereas

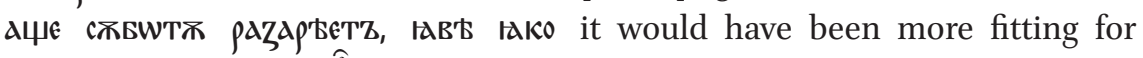

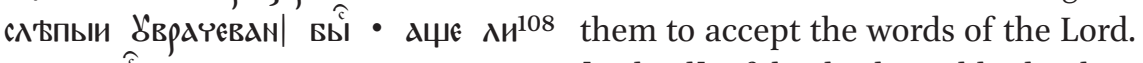

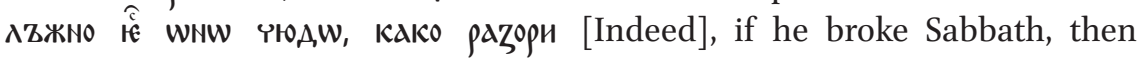

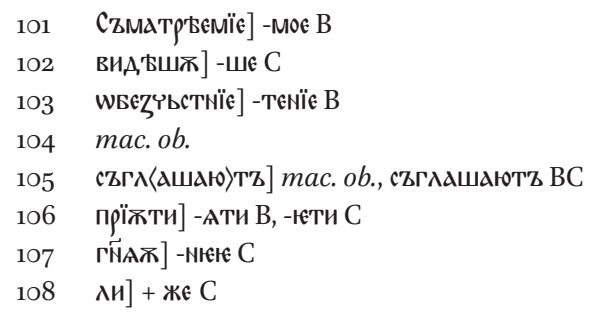




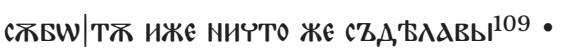
ИАИ ПОКАОПИ СА ФАРИ|СеЎ ЧЮАЕСИ, ИАИ

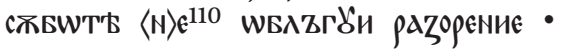

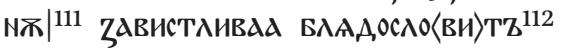

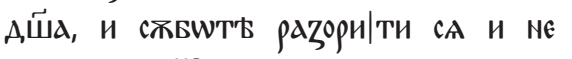
СZА,'АТТИ СА ${ }^{113}$ ЧЮА,ЕСН

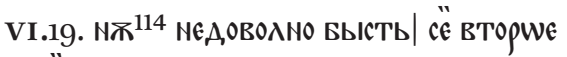

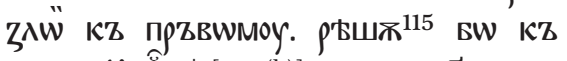

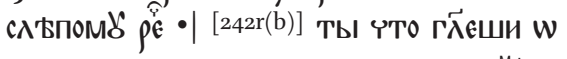

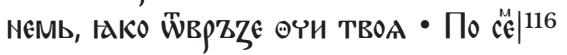

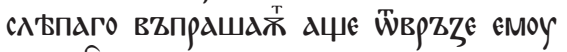

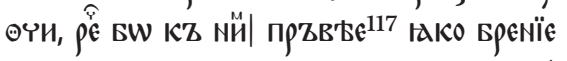
ПОАШЖИ Ка ОҮИ МОН И ОУМЫХ СА И|

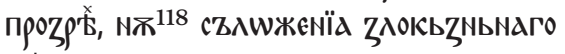
Гत̃Z NAZNAMENA|BAETZ ГАACWBWMЬ

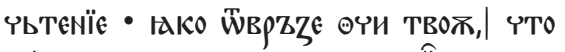

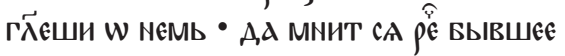
ИСТИNNO •| ААА,ИМЬ БЫТИ NЕАZЖнУ

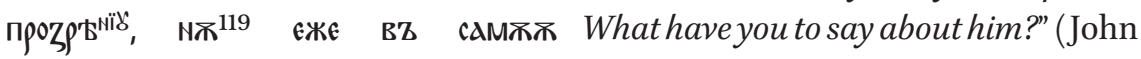

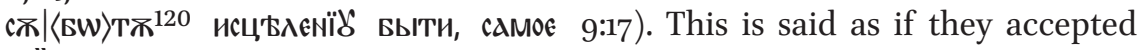

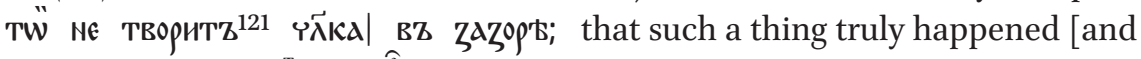

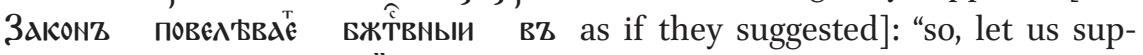
сжБWтж|122 Nє А'СААТи. Т"̈ жє ZакWNZ pose that you did receive sight, and

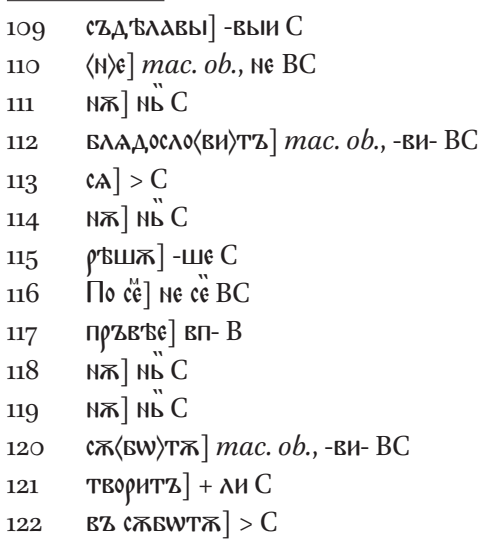

how do you explain that the blind was healed? And if the miracle was fake, then how did he break Sabbath without having done anything? The Pharisees [had to] either bow before the miracle or bring accusations against the breaking of Sabbath. But [their] zealous soul [made them believe] that both Sabbath was broken, and no miracle occurred.

VI.19. Moreover, being unhappy either with this second evil or with the first, they said to the blind, as it is stated: "What have you to say about him? It was your eyes he opened" (John 9:17). The reason they questioned him on whether [Jesus] opened his eyes was that he said earlier "he put a clay on my eyes, and I washed and began to see" (John 9:11). Yet the evil scheme of their made-up question is revealed as we read aloud: "It was your eyes he opened. pose that you did receive sight, and 
КАКW ТВОРЕЦZ С̈̈ ПОПрА •| НА Б'ВА,ЕнЬ САБПЬИ WСКЖА,АЕТ СА С⿱亠⿻⿰丿亅八АГW| ZаКWNZ КААWТворецZ А,ОБР'ИШИ

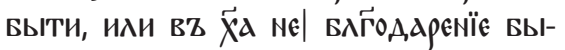

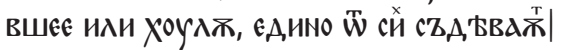

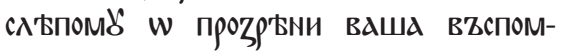
инANÏА •। that to be healed on Sabbath does not make one a criminal. But since God's law commands to do no work on Sabbath, how is it that God breaks this very command?" The poor blind had to make a judgment for himself - either [to say] that the one who gave the law is better than the one who created the earth, or to insult Christ in ungratefulness. The way you, [Pharisees], reconstructed how the blind gained sight leaves him with only one of these two [options].

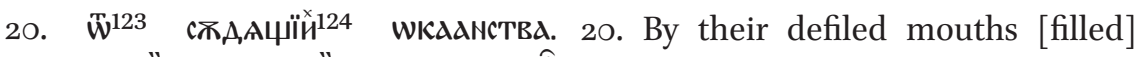
шскврьмнь"ихь оустьм", калотворца ХА் with curses of condemnation, they марнцаххоу'25 сжА,имым вZПАА,АТТZ cursed Christ by calling him a dirtвZ| стрсть, и свон скад $\widetilde{W}$ ска,имаго maker. They fell into affliction and in

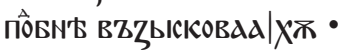
turn found judgment on themselves from the one they condemned.

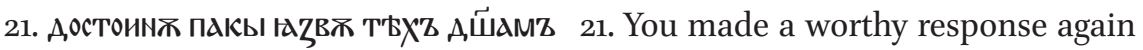

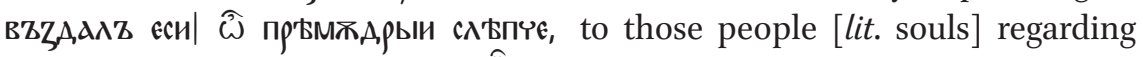

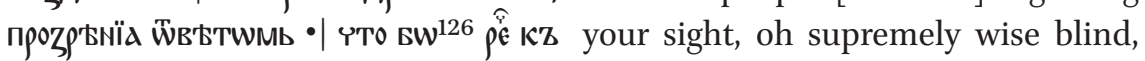

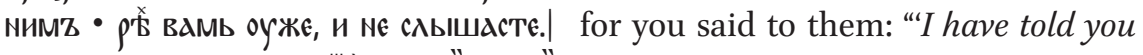

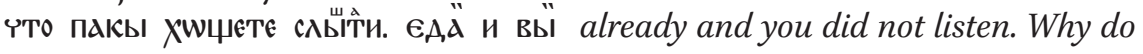

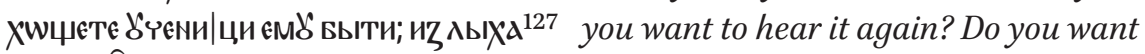

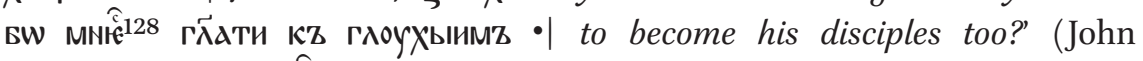
Кын вш ми

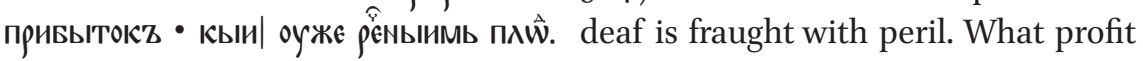
ВZС'ВМИ ${ }^{129}$ ВZ БААА,Ь ВZM'ВNєNА БЫшж.| is there for me from what was previвZсБко кZ моєму истZцамї̈ скомчашж оusly said? What fruit is there from $\mathrm{CA}^{130}$ словесd $\bullet$ мрZтвы БW кZ монмz what has been spoken? It has been

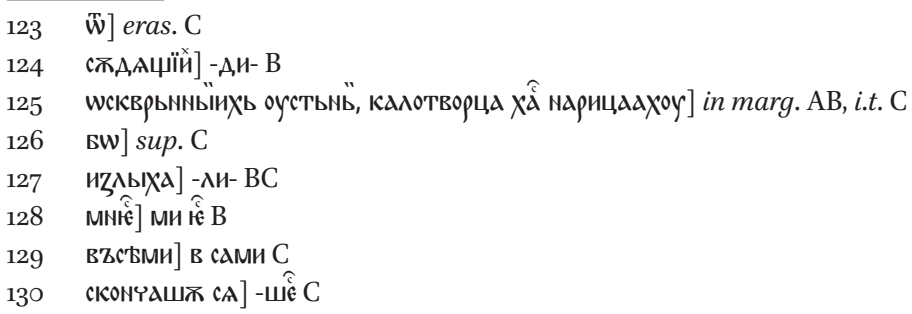




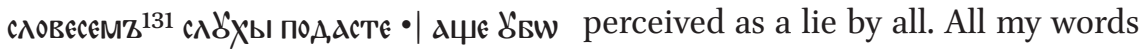

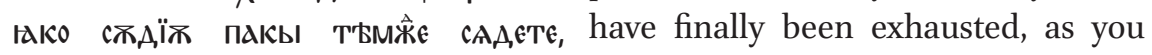
веZГАа|сна МА КZ Ẅв'Втоу оуърите - have turned a deaf ear to my words. So,

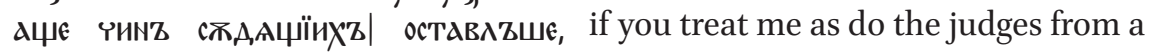
желаNїє оученїчьское вZZMETE, court seat, you will see me voiceless to

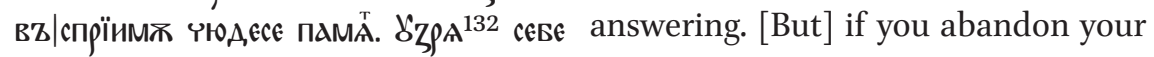

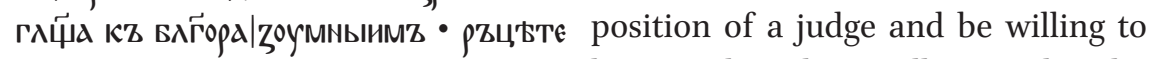

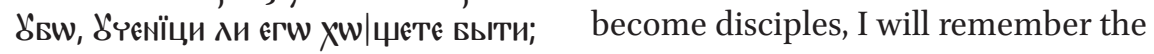
miracle and see myself speaking to the prudent. Tell [me] then, do you want to be his disciples?"

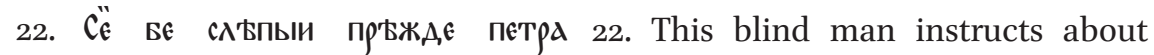
$\boldsymbol{\delta}^{\prime}$ Саморккополшжникъ пока|za сA showed himself to be self-consecrated пр'жає павла -

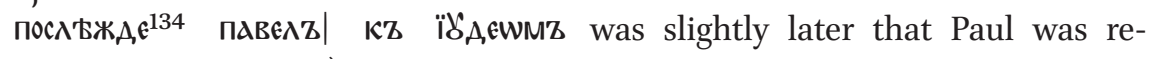

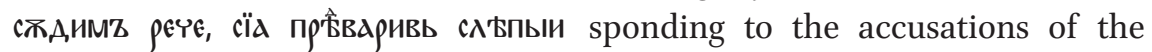

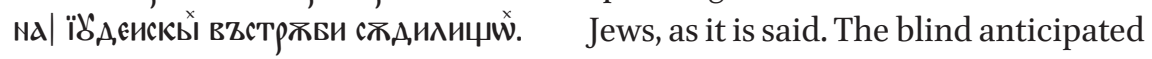
these [two] as he trumpeted [about the miracle] at the Jewish trial court.

23. ТА жє ми и павловш| КZ агрїппоу 23. Remember here also Paul's speech вZспом'Вн'Вте ${ }^{135}$ слово - Взсхыценоу to Agrippa ( $c f$. Acts 26:1-32). For Paul вш ${ }^{136}$ вы|вшоу на скаице павлоу • was brought before the court, and JewїУАєистїн жє сйенници шБлZ|гшвадХ⿸厂 ish priests put forth accusations. At - швеним же скаш̈ агрїппа both trials, Agrippa listened to [the послоушатель •| Глџॅل же павлلे на charges], and Paul won the case in re-

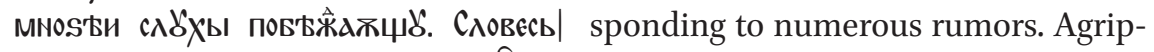
СИА' АГрїпа ПочюА,ИВ СА, ПАВАє мал'Б ма пр'Бпирає|ши выти words. Paul, he said, "Do you [want] to Хрїстїаниноу - Кь пемلٌ же Щ̈в'ьща persuade me to be a Christian in such a

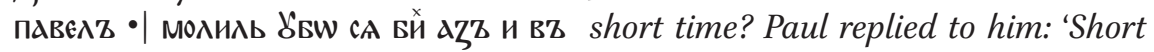

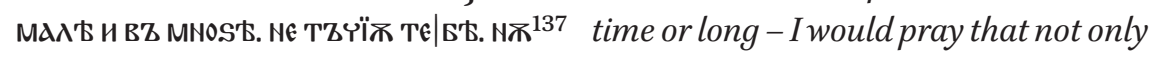

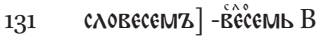

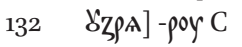

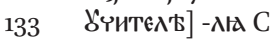

134 ПоС $\Lambda$ 'А,

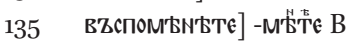

136 Взсхыщеноу] -ни оуво С

137 нж] нั̈ С
} 


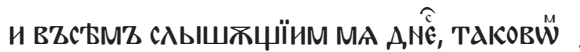
Быти זако you but all who are listening to me today may become what I am"' (Acts 26:2829).

24. С̈тzinn сльпаго павлшв'ьмь, и 24. Compare the blind with Paul, and

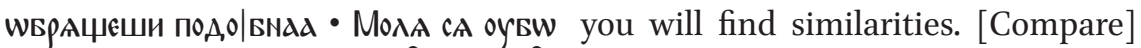

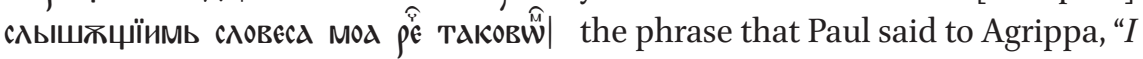
Быти ${ }^{138}$ гакоже $\mathrm{AZZ} \cdot$ - Сїи павлшвZ $\mathrm{kz}$ pray that those who listen to me would

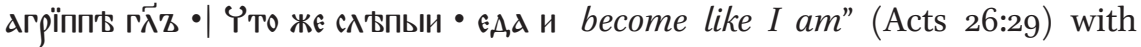
вы Һченїци егш Хшщете Быти| - Сїи what [said] the blind "Do you want to

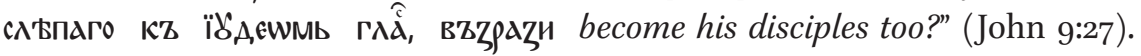

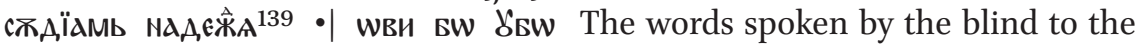

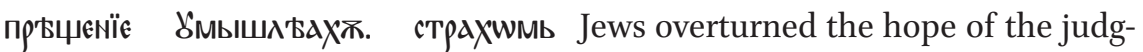
шБлZга|мїА нжжА, въҚлшжити es, for they schemed a punishment, УПовАХщє - WB же покАZАти|140 hoping to force him into trouble by the

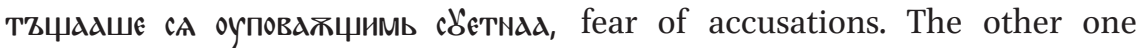
кZ У'ченичьств

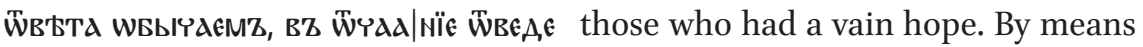

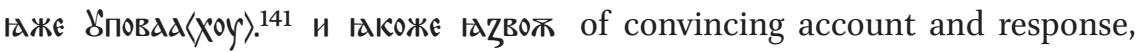
Аюток Zапрь|тивь ть'ХZ вZZА.ражи ${ }^{142}$ he led to despair those with [vain] hope and made it impossible for them to object as if they were [struck] by a bad wound.

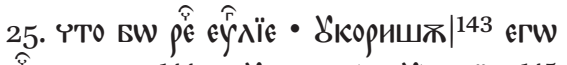

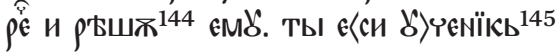
WNWГO. Мы Же [242v(a)] мшйсешви есмы Учемїци - Уૅкар'Ееши егW; $\mathrm{Ne}^{146}$ оука|р'єши. мж ${ }^{147}$ в'ВнчАВАєши reproach of the Pharisees failed to be фарисеठ сльпагш - понашає|ши вш effective and instead, it crowned the

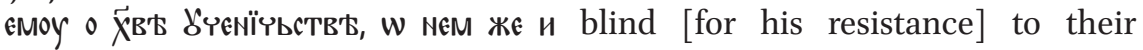

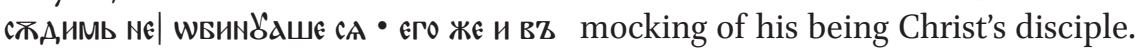




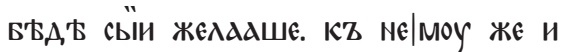
ТеБе понЖжА,Аж ${ }^{148}$ нАлежитZ •
Being judged on account of Christ, he did not give up and desired him in the time of trouble. It is on him I urge you to rely as well!

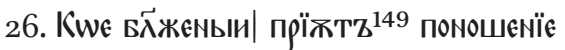

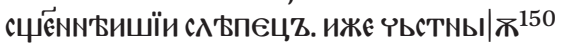

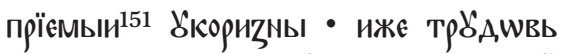

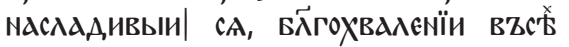

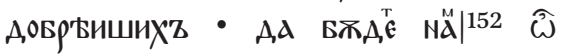
СА'Пче КZ ТАКОВЫНМ А,ОСА,АМЬ ШБџенїє •

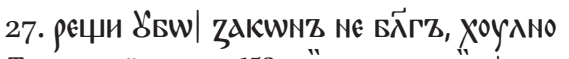

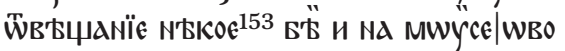

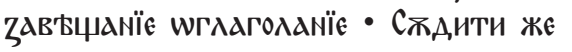
врачева|NÏє, БеZакоnNo. єже вZ

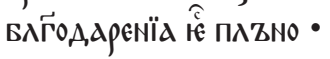

26. What an insult the blessed [and] most holy blind had to bear in the face of charges, himself being an honest man, who after having delighted in [his] deeds is [to be] praised above all virtuous people! May we, oh blind, partake of such offenses.

27. To say then that the law is not good would be [to make] an impious statement and a slander against the Mosaic commandments. And to judge the healing is lawless if you are full of gratitude to Christ.

28. мж $\left.\right|^{154} w$ вшю ршвоу сице сьмотрївь 28. But assessing the danger of the

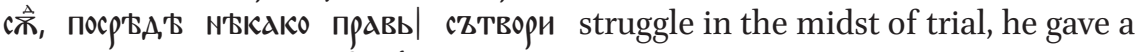

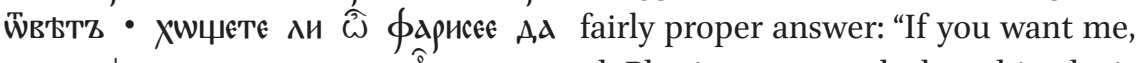

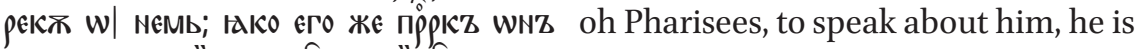

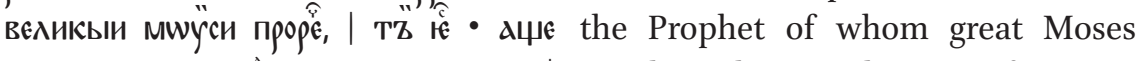

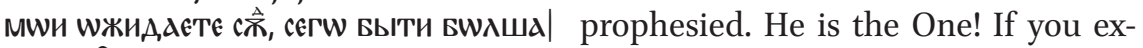

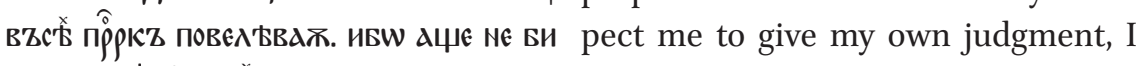
BZ NeMZ EZ, Ne Бй проZ

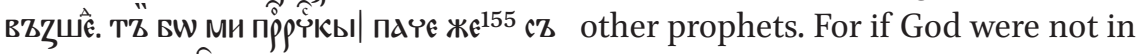

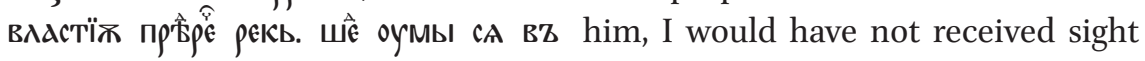
кхп' |Ан снАшамхи и прозри •

\footnotetext{
148 понжжА,Аж]-д,дюе C

149 прїжтZ] приють C

15 О іьстныж]-нык C

151 прїємын] прїємz В

152 mac. ob.

153 N'Bкoe] in marg. B

$154 \mathrm{~N}$ ] N" C

155 жe] $>\mathrm{C}$
} after coming out of Siloam. For that man, as I already said, spoke to me rather authoritatively: 'Go, wash in the Pool of Siloam and you will receive sight"' ( $c f$. John 9:11). 


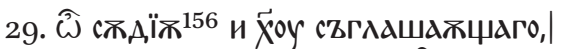

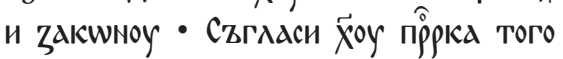
нареКZ, еГW же они| Zаконопр'Беттпника гЛАахж. почьте же ZакWNZ, Zа| КWNa ввй вZС'Б' ${ }^{157}$ присZвъКоупивь. ЕХика БШ А'Тиствова|шж ${ }^{158}$ пр९рци, сїа zаконZ

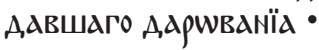

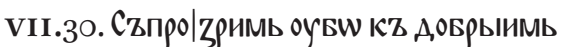

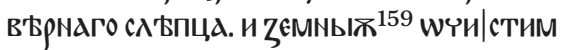

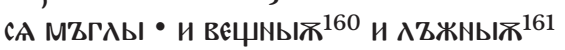

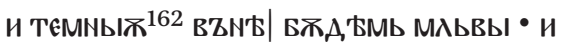

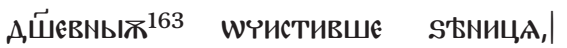
БЫстростї оуМноб WА'ТИМ СА - И ЕЖЕ

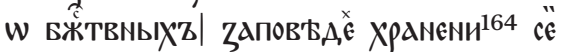

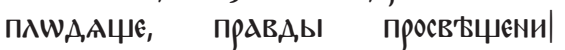

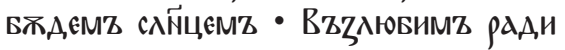

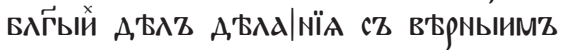

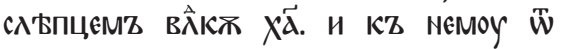

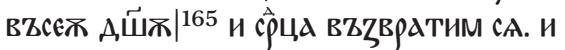

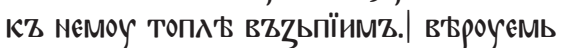
Гй ґако тӹ єси Б̈Z просв'Бщажи ${ }^{166}$ и

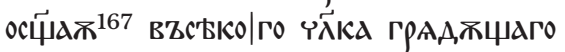
BZ MирZ.

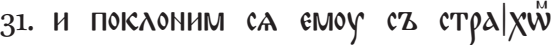
многї и чьстїж. пако томоу пӧває fear and awe, for he is worthy of all вZс'Вка слАва чь|сть и поклАN'ВNïє • сZ praise, honor and worship, together

\footnotetext{
156 скаї̈] -Аия C

157 BZc'b] sup. C

158 А'Тиствовашж] -вАше С

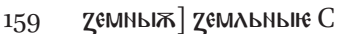

16 вецшныж] -нык $\mathrm{C}$

161 лZжмыж] -нык $\mathrm{C}$

162 темныж]-ные С

163 Аш̈євныж] -нык С

164 ХрАнени] -ниюе $\mathrm{C}$

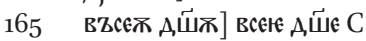

166 просв'Вщажн] -цакен С

167 осщ山а] - џак $\mathrm{C}$
}

29. Oh judge, in acknowledging Christ and the law, acknowledge Christ whom they said was the law-breaker to be called Prophet. Honor the law, ascribing to God whatever is according to the law. For the prophets acted based on the gift of that law.

VII.30. So, let us too receive sight [to see] the good [example] of the faithful blind and purify ourselves from the earthly darkness! [Let us] stay away from the material and false and dark vanity [of this world]! And having purified the eyes [lit. pupils], may we clothe our mind with vigilance! And as we bear these fruits by keeping the divine commands, the sun will enlighten us toward truth. May we, together with the faithful blind, love the Lord Jesus in order to do good deeds, and turn to him with our whole soul and heart, and cry out to him with fervor: "We believe, Lord, that you are the God who gives light and sanctifies every man coming into the world" (cf. John 1:9).

31. And let us worship him with much 


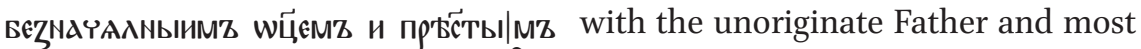

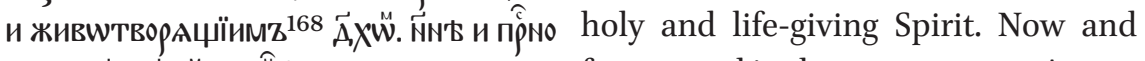

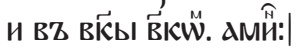
forever and in the ages to come. Amen.

\section{Acknowledgement}

Viacheslav V. Lytvynenko's work on this article was funded by the Charles University Research Center Program No. 204053.

This paper is part of the larger project aimed at identifying and classifying all texts (both genuine and pseudographic) that are ascribed to Athanasius of Alexandria in the Slavonic tradition. The end goal of this project will be a book, Slavonic Athanasiana.

168 живштворацїнмz] тв lig. 